\title{
Implementation of Lean Manufacturing in Romanian Organisations
}

\author{
Camelia Ioana Ucenic $^{1, *}$ and Claudiu Ratiu ${ }^{1}$ \\ ${ }^{1}$ Technical University Cluj Napoca, Faculty of Machine Building, Romania
}

\begin{abstract}
The implementation of lean manufacturing is one of the main tools for attaining a higher performance level in the Romanian organisations. The study uses data collected at middle management level from organisations located in Transylvania. The organisations come from different fields of activity and are in different stages of lean implementation. The article makes use of quantitative and qualitative instruments for the evaluation of lean in the above mentioned companies. Characteristics as waste reduction, cost, quality, product design have different approaches in the companies. Their way of approach gives useful information regarding the type of company from the point of view of lean manufacturing implementation. This knowledge provides a useful support at different managerial levels in the process of decision making.
\end{abstract}

\section{Introduction}

Taiichi Ohno and Shigeo Shingo developed the production systems of Toyota. The book written by Womak - "The Machine which changed the World" promoted their work and made well known the concept of lean production. The application of lean manufacturing principles took a rapid advance in many fields of activity. A lot of companies obtained better results due to lean manufacturing. Airbus, Philips and Rolls Royce are among the brands which implemented lean.

Lean manufacturing is not a universal receipt for success. Not all organisations which tried to apply it reached all the proposed goals. The literature review reveals situations when the company obtained a primary advantage but latter on it was not able to carry on the continuous improvement process. There are many reasons for the failure or for the delay in targets. One of the main reasons for the failure is the insufficient employee education regarding lean manufacturing values. This problem occurred at different managerial levels.

Different lean manufacturing frameworks were proposed. They include various tools, techniques and procedures [1]. Many of them only describe the lean elements. The number of elements which are included in a framework fluctuate from 3 to a maximum 50 elements [2]. The minimum attention given to the stakeholders is a common accuse of these frameworks. The internal stakeholders are the shop floor workers, the executives and the managers. They have different perspectives at a certain moment. The success or the failure of lean implementation depend on the equilibrium point among them.

\footnotetext{
*Corresponding author: cameliaucenic@gmail.com
} 


\section{The principles of lean manufacturing}

The main objective of lean is to eliminate the non-value added elements from a process. The elimination of waste at each stage provides competitive advantage for the organisation. Womak and Jones proposed 5 lean principles:

- Identify the value;

- Map the value stream;

- Create the flow after the elimination of waste from the value stream;

- Establish pull and decrease the time to customer;

Look for perfection and make lean a part of corporate culture [3]. A correct implementation of lean requires the involvement of all employees.

Lean is associated more often with manufacturing but are many other fields where was implemented. The service sector benefits a lot after lean implementation. Last but not least are: information technology, software development and maintenance [4].

Swamynathan and Sekkizhar determined that lean means more than a collection of managerial tools. They explained that lean is a viewpoint of continuous improvement that approaches organizations from a systemic perspective [5].

\subsection{Traditional organisation versus lean organisation}

There are different characteristics which have to be analysed in order to correctly determine the type of an organisation: traditional or lean organisation.

A traditional organisation has the following features:

- The demand is unpredictable

- The producer has the responsibility for the product design

- A low priority is given to the elimination of waste

- The products are standard

- Operations are associated with the most important costs

- The percentage of defective products define the quality performance.

- The supply chain has a moderate capacity to absorb the risk.

A lean organisation is characterised by:

- A predictable demand

- The producer has the responsibility for the product design - same as in traditional organisation

- The elimination of waste has a basic priority

- The products are functional

- Operations are associated with the most important costs- same as in traditional organisation

- The percentage of defective products define the quality performance - same as in traditional organisation

The supply chain has a low capacity to absorb the risk [6].

Many Romanian companies are defined as hybrid organisations. Their demand is unstable and unpredictable. Quality performance has a new way to be measure using the degree of customer satisfaction. The marketing costs are included together with the operation costs in the most important costs. The producer and the customer have the responsibility for the product design. The same as in the traditional organisation, the supply chain has a moderate capacity to absorb the risk [7].

\subsection{Correlation between lean principles and their defining elements}

The above mentioned five lean principles are explained by the following components: 
- Waste reduction

- Order based production

- Customer focus

- Continuous improvement

- Partnership with suppliers.

The waste reduction has as targets the following elements: work in progress, lead time reduction, design for manufacturing, one piece flow and a flat organisational structure. Top management is responsible for the organisational structure and the other goals are tasks for middle management.

Order based production make use of small lot production, pull production, rolling production plans, Kanban system and just in time delivery. Suppliers respond by the just in time delivery. The same practice is considered within the workstations. The other elements are the responsibility of manufacturing department.

To be customer focus means to be in charge with value stream mapping, concurrent engineering, cellular manufacturing, standardisation of parts, and use of small multiple machines. First three elements are associated with the top management level and the last two with the manufacturing.

Continuous improvement implies product simplification, storage reduction, and elimination of buffers, total productive maintenance and new equipment. Top management respond for last two and manufacturing for the other elements.

Supplier partnership has as goals supplier reduction, sole source, long term relationships, supplier proximity and information sharing [8].

\section{Methodology}

The Kano model was used for this study. The model was presented first time in 1984 and requires a list of potential needs that the process should try to satisfy. Its selection was done because Kano model is recommended as a tool in the process of lean implementation because develops a set of ideas for planning a process or a service. Another reason for model selection was the insufficient employee education in lean attributes [9].

The novelty of this study in comparison with the classical Kano model is the substitution of customers with the internal stakeholders represented by the middle managers. The middle management is responsible for many components which define the lean elements and principles.

The attributes performance of the lean process is not equal for the managers. The performance of some attributes generate higher levels of satisfaction in comparison with other attributes.

A number of 24 middle managers participated at oral interviews. They come from six enterprises located in Cluj-Napoca, Alba-Iulia, Satu-Mare and Bistrita-Nasaud. The companies have implemented lean manufacturing and are in different stages of continuous improvement process.

The number of participant - 24 managers - is in correlation with the prescriptions of literature review. The theory says that 20 to 30 interviews which take place in homogeneous segments are appropriate in order to determine 90 to $95 \%$ of all possible process requirements [10].

The requirements are categorised by questionnaire. Each question has two parts:

- The functional form of the question: How do you feel if characteristic " $\mathrm{X}$ " is present in the process?

- The dysfunctional form of the question: How do you feel if characteristic " $\mathrm{X}$ " is absent in the process?

The answer has to be in one of the next five possibilities: 
Table 1. Kano requirements.

\begin{tabular}{|c|c|}
\hline Code & Meaning \\
\hline $\mathrm{A}$ & attractive \\
\hline $\mathrm{M}$ & Must be \\
\hline $\mathrm{O}$ & One dimensional \\
\hline $\mathrm{I}$ & indifferent \\
\hline $\mathrm{R}$ & reversed \\
\hline $\mathrm{Q}$ & questionable \\
\hline
\end{tabular}

Table 2. Kano requirements.

\begin{tabular}{|c|c|}
\hline Code & Meaning \\
\hline \multirow{5}{*}{$\begin{array}{l}\text { If characteristic " } \mathrm{X} \text { " is } \\
\text { good how do I feel? }\end{array}$} & 1. I like it in this way \\
\hline & 2. It must be in this way \\
\hline & 3. I am neutral \\
\hline & 4. I can live with it in this way \\
\hline & 5. I dislike it in this way \\
\hline \multirow{5}{*}{$\begin{array}{l}\text { If characteristic " } \mathrm{X} \text { " is } \\
\text { poor how do I feel? }\end{array}$} & 6. I like it in this way \\
\hline & 7. It must be in this way \\
\hline & 8. I am neutral \\
\hline & 9. I can live with it in this way \\
\hline & 10. I dislike it in this way \\
\hline
\end{tabular}

\section{Case study: the level of implementation of lean manufacturing in Romanian organisations}

The goal of this study was to evaluate how perceive the middle managers from companies from Transylvania the level of implementation of lean manufacturing. As was previously presented one of the main reasons for the failure in lean processes is the insufficient employee education regarding lean manufacturing values.

The selected companies have manufacturing as object of activity. Lean manufacturing is in different stages of implementation. Due to confidentiality reasons neither the companies nor the names of middle managers are not revealed.

The following table presents an example of Kano analysis. The analysis considers nine lean characteristics. It was done using the framework proposed by Agile Logic.

A discrete analysis was done in the second step of the model. Each manager's answer was categorised using the evaluation table, as was presented in table 3. It was calculated the number of total responses for each category and each lean characteristic. The most frequent answer will define the characteristic. The ranking is as following:

- Must-be $>$ Performance $>$ Attractive $>$ Indifferent

- The decrease of work in progress and a small production lot are must be characteristics for lean manufacturing. The category "performance" includes lead time decrease, standardisation of parts and elimination of buffer. The rolling production plan is the only attractive feature. 
Table 3. Example of Kano analysis evaluation.

\begin{tabular}{|c|c|c|c|}
\hline Story Narrative & $\begin{array}{c}\text { How would } \\
\text { you feel if this } \\
\text { was present? }\end{array}$ & $\begin{array}{c}\text { How would you } \\
\text { feel if this was } \\
\text { absent? }\end{array}$ & Priority \\
\hline $\begin{array}{c}\text { lead time decreases } \\
\text { Expect It }\end{array}$ & Dislike & Must-Be \\
\hline $\begin{array}{c}\text { organisational structure not } \\
\text { flat enough }\end{array}$ & Don't Care & Live With & Indifferent \\
\hline $\begin{array}{c}\text { design for manufacturing has } \\
\text { problems }\end{array}$ & Dislike & Expect It & $\begin{array}{c}\text { Reversal } \\
\text { (invalid) }\end{array}$ \\
\hline $\begin{array}{c}\text { small lot production } \\
\text { rolling production plan }\end{array}$ & Don't Care & Dislike & Must-Be \\
\hline standardisation of parts & Expect It & Don't Care & Indifferent \\
\hline elimination of buffer & Expect It & Live With & Indifferent \\
\hline product simplification & Expect It & Dislike & Must-Be \\
\hline
\end{tabular}

Table 4. Kano requirements.

\begin{tabular}{|c|c|c|c|c|c|c|c|c|}
\hline Characteristics & M & P & A & I & R & Q & Total & Class \\
\hline work in progress decreases & 11 & 3 & 2 & 5 & 1 & 2 & 24 & M \\
\hline lead time decreases & 4 & 6 & 3 & 4 & 2 & 5 & 24 & P \\
\hline organisational structure not flat enough & 5 & 4 & 6 & 9 & 0 & 1 & 24 & I \\
\hline design for manufacturing has problems & 3 & 1 & 6 & 4 & 1 & 10 & 24 & Q \\
\hline small lot production & 9 & 4 & 7 & 2 & 1 & 1 & 24 & M \\
\hline rolling production plan & 4 & 3 & 8 & 4 & 3 & 2 & 24 & A \\
\hline standardisation of parts & 3 & 10 & 6 & 4 & 1 & 0 & 24 & P \\
\hline elimination of buffer & 2 & 8 & 5 & 4 & 2 & 3 & 24 & P \\
\hline product simplification & 3 & 5 & 5 & 7 & 2 & 2 & 24 & I \\
\hline
\end{tabular}

\section{Conclusions}

The article makes use of quantitative and qualitative instruments for the evaluation of lean in enterprises from Transylvania. The quantitative instrument was Kano model. These firms are in different levels of the lean manufacturing implementation. Twenty four middle managers participated at the interviews. They are considered as internal stakeholders. The model interpretation was done using discrete analysis. 
Nine lean characteristics are in the model. Two are must be features, three are performance features, just one is attractive, two indifferent, and one questionable. The model can be developed by adding new lean manufacturing features. New companies have to be tested. A limitation of this study was the fact that all companies are from manufacturing. The model will have a greater value if other types of firms are involved in the study.

Last but not least, the discrete analysis can be replaced with the continuous analysis.

\section{References}

1. G.C. Parry, C.E. Turner, Production Planning \& Control, 17 (1), 77 (2006)

2. G. Anand, R. Kodali, R., Int. J. Services and Operations Management, 5 (5), 687 (2009)

3. J.P. Womack, D.T. Jones, Lean Thinking: Banish Waste and Create Wealth in Your Corporation, New York: Simon \& Schuster. (1996)

4. R. Bradley, D. M. Upton. "Lean Principles, Learning, and Software Production: Evidence from Indian Software Services”. Harvard Business School Working Paper. No. 08-001 (2007)

5. A. Constancioara, G.L. Florian, O. Brad, Proceedings of the 9th International Management Conference, "Management and Innovation For Competitive Advantage", Romania, 940 (2015)

6. S. Konecka, Electronic Scientific Journal of Logistics, 6 (4), 24 (2010).

7. R. Parthipan, J. Anto, V. Nirmalkannan,. Int. J. of Innovative Research in Science, Engineering and Technology, 4 (2), 91 (2015).

8. R. Alas, Int. J. Services and Operations Management, 4 (4), 481 (2008)

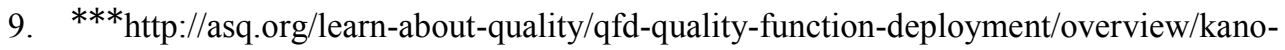
model.html

10. L. Phillips: www.businessmeccanica.blogspot.com

11. *** Agil Logic Excel worksheetsheet for Kano analysis 